\title{
Revision of the Lacinipolia vicina (Grote) complex (Noctuidae, Noctuinae, Eriopygini)
}

\author{
B. Christian Schmidt' \\ I Canadian National Collection of Insects, Arachnids and Nematodes, Agriculture and Agri-Food Canada, \\ K.W. Neatby Bldg., 960 Carling Ave., Ottawa, ON, Canada K1A 0C6 \\ Corresponding author: B. Christian Schmidt (Chris.Schmidt@inspection.gc.ca)
}

Academic editor: D. Lafontaine | Received 24 March 2015 | Accepted 9 May 2015 | Published 15 October 2015

http://zoobank.org/3A7D6C6E-7837-4B1F-A82A-0B6975E958B9

Citation: Schmidt BC (2015) Revision of the Lacinipolia vicina (Grote) complex (Noctuidae, Noctuinae, Eriopygini). In: Schmidt BC, Lafontaine JD (Eds) Contributions to the systematics of New World macro-moths VI. ZooKeys 527 : 103-126. doi: 10.3897/zookeys.527.9686

\begin{abstract}
The Lacinipolia vicina (Grote) species complex, previously consisting of L. vicina, L. teligera (Morrison), L. pensilis (Grote), and L. subalba Mustelin is revised to six species: L. vicina (eastern USA), L. teligera (southern Great Plains), L. pensilis (Pacific Northwest and northern Rocky Mountains), L. acutipennis (Grote), stat. rev. (= L. subalba syn. n.) (western North America), L. sareta (Smith), stat. rev. (Canada and western USA) and L. dimocki, sp. n. (California and Pacific Northwest). Lectotypes are designated for L. vicina, L. teligera and L. pensilis.
\end{abstract}

\section{Keywords}

Cryptic species, Pacific Northwest, California

\section{Introduction}

Lacinipolia McDunnough is currently one of the largest North American noctuid genera with 61 species, and includes another 10 species described from Mexico and Central America. The diversity centers for Lacinipolia are the arid habitats of the American Southwest and Mexico. Like many of the constituent genera of the 
Eriopygini, a diverse, largely New World tribe, the current concept of Lacinipolia is not monophyletic and in need of revision. Lloyd Martin initiated this considerable undertaking in the 1960s, but abandoned the project after the loss of all his notes and type photographs (Leuschner 1992). Selman (1975) based his unpublished thesis dissertation on the earlier work of Lloyd Martin, and since Selman's thesis was never published, Selman and Leuschner (2001) described the nine new species treated therein. Within Lacinipolia (sensu stricto), the L. vicina (Grote) group previously consisted of four species, here revised to six species.

\section{Methods and materials}

Adult genitalia were prepared following the methods of Lafontaine (2004). Cleaned, stained genitalia were stored and examined in 30\% ethanol, and slide-mounted in Euparal before being photographed using a Nikon D200 digital camera. Distribution maps for examined material were generated using SimpleMappr (Shorthouse 2010).

\section{Repository abbreviations are as follows}
AMNH American Museum of Natural History, New York, NY
BMNH The Natural History Museum (statutorily: British Museum [Natural History]), London.
CNC Canadian National Collection of Insects, Arachnids and Nematodes, Ottawa, ON
USNM National Museum of Natural History (formerly United States National Museum), Washington, DC
MCZ Museum of Comparative Zoology, Cambridge, MA
MSU Michigan State University, East Lansing, MI
CUIC Cornell University, Ithaca, NY

Variation of the 'barcode' section of the COI gene was compared among 264 specimens representing all six species (Suppl. material 1). DNA extraction, PCR amplification, and sequencing of the COI barcode region were performed at the Canadian Centre for DNA Barcoding (CCDB) and followed standard protocols (Hajibabaei et al. 2005; Ivanova et al. 2006; deWaard et al. 2008; Hebert et al. 2013; http://www. ccdb.ca/resources.php). PCR and sequencing generally used a single pair of primers: LepF1 (ATTCAACCAATCATAAAG ATATTGG) and LepR1 (TAAACTTCTGGATGTCCAAAAAATCA) (Hebert et al. 2004) which recovers a 658 bp region near the 5 ' end of COI including the $648 \mathrm{bp}$ barcode region for the animal kingdom (Hebert et al. 2003). Only sequence records greater than 500 bp (range 500 bp-658 bp) are included. 


\section{Systematics}

\section{Key to species of the Lacinipolia vicina group}

Male

Female

Spines posterior to juxta ('above' juxta in slide preparations) pointing anteroventrally and forming spinose crests or simple patch ${ }^{1}$ (Figs 55-58) Spines posterior to juxta pointing postero-dorsally and situated on inside surface of spade-like plate (Figs 59, 60)

3 Medial field of ventrally projecting spines located adjacent to juxta (Figs 55,

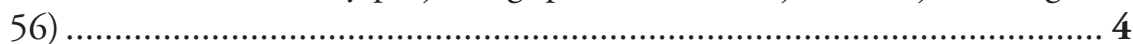

- $\quad$ No medial spine patch adjacent to juxta(Figs 57,58$)$.............................. 5

$4 \quad$ Clasper with thumb positioned at basal third of distance to apex (Fig. 55); hindwing with dark fuscous terminal shade (Figs 1,2); occurring east of the Mississippi Valley (Fig. 69)

L. vicina

- $\quad$ Clasper with thumb positioned nearly halfway to apex (Fig. 56); hindwing without dark fuscous terminal shade (Figs 4, 5); occurring west of the Mississippi Valley (Fig. 70)

L. teligera Crest of phallus usually with a thin, delicate apically-directed spine (sometimes broken off, in which case base is still evident) (Fig. 61), or if thin spine absent, then entire crest reduced with fewer and smaller cornuti (Fig. 61c); forewing ground colour highly variable, but medial area concolourous with postmedial and antemedial areas, and antemedial line absent or poorly defined; usually with apical pale area that extends through postmedial line into reniform spot; subterminal area usually darker than postmedial area; reniform and orbicular spot often only faintly visible; orbicular spot sometimes flattened and elongated; arid low elevation habitats including shortgrass prairie and sagebrush steppe.

L. acutipennis

- $\quad$ Crest of phallus never with a thin, delicate basally-directed spine (Fig. 62), rarely with robust cornutus directed apically (Fig. 62h); forewing ground colour varying in saturation but consistent in tone, with medial area containing brown tones that are lacking in the grey-and-black postmedial and antemedial areas; antemedial line usually well defined; pale apical area not extended through postmedial line; subterminal area not darker than postmedial area; reniform and orbicular spot conspicuous, paler than ground; orbicular spot never highly flattened and elongated; low to high elevation woodland, particularly dry, montane pine and Douglas-fir woodlands

L. pensilis

The spine field above the juxta and even the aedeagal cornuti can often be examined without dissection by carefully removing the terminal abdominal hairs with a small brush, especially if the valves have previously been spread by squeezing the base of the genital capsule when specimen is still fresh. 
Clasper with a thumb-like process on ventral margin, clasper flattened and apex rounded; digitus pointed (Fig. 59); widely distributed, including West Coast states (Fig. 73) L. sareta

- $\quad$ Clasper without process, shaped like a sinuate spine with a pointed apex; digitus rounded (Fig. 60); West Coast states (Fig. 74) L. dimocki

7 Ostium asymmetrical, like opening of a conch; margin of prevaginal plate straight or slightly convex (Figs 63-66). 8 Ostium symmetrical, opening simple; margin of prevaginal plate strongly convex (Figs 67, 68).

Ostium complex 1.4-1.5 $\times$ longer than wide; caudal portion of ostial slit gradually curved (Figs 65, 66)

Ostium complex 1.0-1.1 $\times$ longer than wide; caudal portion of ostial slit sinuate (Figs 63, 64)

Forewing ground colour highly variable, but medial area concolourous with postmedial and antemedial areas, and antemedial line absent or poorly defined; usually with apical pale area extended through postmedial line into reniform spot; subterminal area usually darker than postmedial area; reniform and orbicular spots often only faintly visible; orbicular spot sometimes flattened and elongated; arid low elevation habitats including shortgrass prairie and sagebrush steppe.

L. acutipennis Forewing ground colour varying in saturation but consistent in tone, with medial area containing brown tones that are lacking in grey-and-black postmedial and antemedial areas; antemedial line usually well defined; pale apical area not extended through postmedial line; subterminal area not darker than postmedial area; reniform and orbicular spot conspicuous and paler than ground; orbicular spot never highly flattened and elongated; low to high elevation woodlands, particularly dry, montane pine and Douglas-fir woodland

L. pensilis

10 Basal half of hindwing conspicuously lighter than marginal portion and forewing (Fig. 6); occurring in southern Great Plains west of Mississippi River (Fig. 70).

L. teligera

- $\quad$ Basal half of hindwing nearly as dark as marginal portion and forewing (Fig. 3); occurring in the eastern United States east of Mississippi River (Fig. 69)...

L. vicina

11 Ductus bursae highly flattened dorsoventrally, with pronounced ribbon-like oblique fold (Fig. 67); corpus bursae 2-2.5 × diameter of ducts bursae; widely distributed, including West Coast states (Fig. 73)

L. sareta

- $\quad$ Ductus bursae moderately flattened dorsoventrally, with slight oblique fold; corpus bursae 3-4 x diameter of ductus bursae (Fig. 68); West Coast states from Washington to California (Fig. 74) L. dimocki 


\section{Lacinipolia vicina (Grote, 1874)}

Figs 1-3, 55, 69

Mamestra vicina Grote, 1874a: 156.

Mamestra imbuna Smith, 1905a: 201, syn. rev.

Type material. Mamestra vicina: The type material of L. vicina almost certainly consisted of two species, the eastern species known previously as $L$. imbuna or $L$. teligera (Franclemont and Todd 1983) and represented by a female syntype from Massachusetts (BMNH; examined), in addition to the widespread species previously called $L$. vicina, represented by at least one syntype from St. Catherines, Ontario (lost). I was unable to locate any St. Catherines specimens, stated by Grote to have come from George Norman. Other syntypes from the Norman collection (Crocigrapha normani (Grote) and Xestia normanianus (Grote)) are also considered to be lost (D. Lafontaine pers. comm.). This is unfortunate since it would have been preferable to fix the name vicina as the widespread, well-known species here treated as $L$. sareta, but as the only extant primary type, the following female specimen $[\mathrm{BMNH}]$ must be designated as lectotype: "Mamestra / vicina / Type Grote" [red-bordered label]; "Type" [round redbordered label]; "vicina / TYPE" [small handwritten label]; Grote Coll. / 81-116." [type-written label]; "U.S.America." [type-written label]; "Noctuidae / Brit. Mus. slide / No. 8237" [blue type-written label]. Type locality: "Massachusetts".

Mamestra imbuna: Male lectotype (AMNH; examined), designated by Todd (1982). Type locality: Luzerne Co., Pennsylvania. The original type series of Mamestra imbuna probably also included L. sareta from the southern Lake Michigan region, as Smith (1905a) mentions an August specimen from Hessville, Indiana (a suburb of Chicago), but Todd's lectotype designation fortunately restricts the concept of the name.

Diagnosis. Within the eastern North American range of L. vicina, L. sareta is most similar but the two can usually be separated without dissection by the more southern distribution, larger size and bivoltine spring / fall flight (April-May and September - October) of $L$. vicina (univoltine from late June to early August for $L$. sareta). In the male genitalia, L. vicina differs most obviously in the arrangement of the spines above the juxta, consisting of two lateral and one medial field of ventrally projecting spines, whereas in $L$. sareta the spines are directed dorsally and are on the inside of a large, rhomboid plate. Females of $L$. vicina have an asymmetrical, invaginated ostium, like the opening of a conch, compared to a simpler ostium with a convex prevaginal plate margin in L. sareta.

Although L. vicina is most closely related to L. teligera, L. vicina and L. teligera are not likely to be confused given the range disjunction and more extensive dark fuscous shading of the hindwing in L. vicina. The male genitalia differ in the shape of the clasper, with the apical lobe narrower and more pointed in L. vicina, and the thumb-like lobe situated one third the distance from the base, compared to halfway in L. teligera.

Distribution and biology. Specimens of L. vicina were examined from Massachusetts, New York, Pennsylvania, Virginia and North Carolina (Fig. 69); Forbes (1954) also cites New Jersey (Lakehurst) and Indiana records. The Indiana record (Smith 


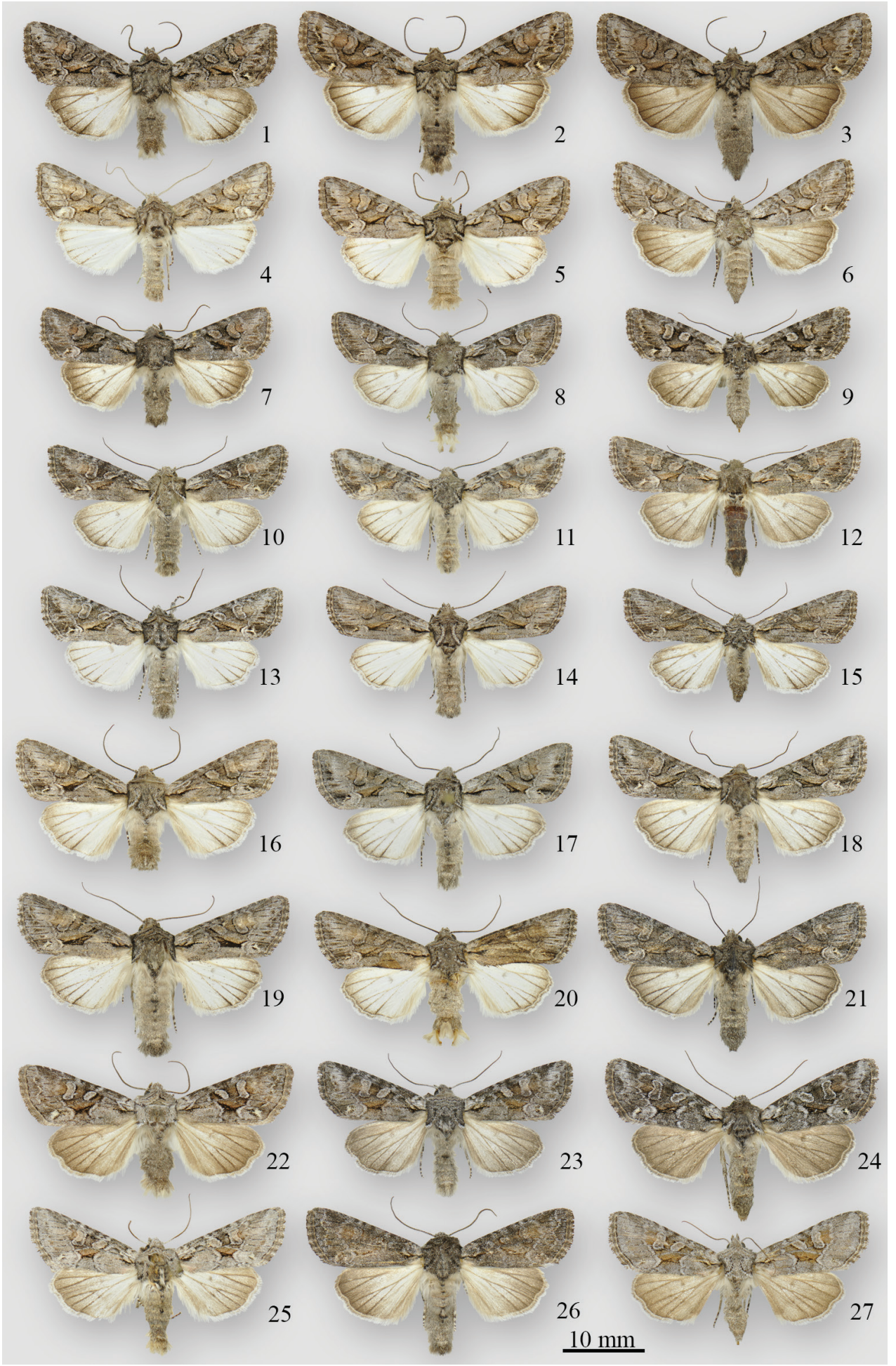


1905a) may be erroneous given the long-standing confusion with L. sareta, as discussed in the "Type material" section above. Eastern Ohio records of L. teligera from May and September given by Rings et al. (1992) are most likely L. vicina. Moore's (1955) records for Michigan probably all apply to L. sareta based on flight dates and the widespread distribution of L. sareta in the Great Lakes region. There is no clear indication of habitat preference; in North Carolina L. vicina occurs in open oak-hickory forest (B. Sullivan pers. comm.). Despite the relatively broad distribution and apparent lack of specialized habitat requirements, L. vicina records are few. Lacinipolia vicina is apparently bivoltine, flying in spring (April-May) and in late summer to early fall (late August to early October), with later dates farther south. The larvae were described and illustrated by Godfrey (1972) (reared vouchers examined; CUIC), and are probably polyphagous ground dwellers like other Lacinipolia (Wagner et al. 2011).

Remarks. As defined here, L. vicina is the same species later described by Smith (1905a) as Mamestra imbuna, differing considerably in morphology from both L. sareta (= vicina of authors) and L. pensilis, although more closely related to the latter. Lacinipolia imbuna was previously treated as a junior synonym of $L$. teligera (Franclemont and Todd 1983).

\section{Lacinipolia teligera (Morrison, 1875)}

Figs 4-6, 56, 64, 70

Mamestra teligera Morrison, 1875: 215.

Type material. Morrison's original description was based on two specimens, and Wilterding (1997) discussed two Morrison specimens in the MSU collection: a male with two conflicting locality labels (Texas and New York), and a damaged female

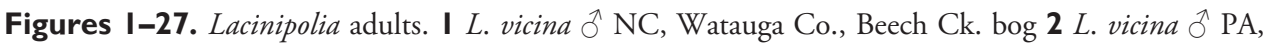
Beaver Co., 6 mi SW Darlington 3 L. vicina 9 PA, Beaver Co., 6 mi SW Darlington 4 L. teligera ô TX, Lampasas Co., Lampasas R. 8 mi S Rte. 1905 L. teligera ô TX, Travis Co., Austin 6 L. teligera $q$ TX, Lampasas Co., Lampasas R. 8 mi S Rte. 1907 L. sareta Ô ON, Manitoulin Is., Dominion Bay dunes 8 L. sareta $\widehat{O}$ BC, [Lillooet], Kirby Flats Rd. 9 L. sareta $\subsetneq$ ON, Manitoulin Is., Sheguindah 10 L. sareta $\widehat{\partial} \mathrm{AB}$, Waterton Lakes NP, Blakiston Ck. fan II L. sareta ô AB, Manyberries, Pakowki Dunes 12 L. sareta $+\mathrm{AB}$, Manyberries, Pakowki Dunes 13 L. sareta $\widehat{A} \mathrm{CA}$, Mono Co., Lee Vining 14 L. sareta $\widehat{A} \mathrm{AZ}$, Cochise Co., Huachuca Mtns, Ash Cyn. Rd. 15 L. sareta + AZ, [Maricopa Co.], Congress 16 L. dimocki §CA, Plumas Co., Jackson Ck., DNA voucher \# CNCNoctuoidea7972 17 L. dimocki ô Holotype, CA, Ventura Co., Cuyama Valley, Apache Cyn. 18 L. dimocki + Paratype, CA, Ventura Co., Cuyama Valley, Apache Cyn. 19 L. dimocki ô WA, Klickitat Co., Simcoe Butte 20 L. dimocki ô WA, Klickitat Co., Munson Prairie 2 I L. dimocki + WA, Yakima Co., South Fork Ahtanum Cr. 22 L. pensilis ô BC, Squamish, Diamond Head Trail 23 L. pensilis ổ BC, [11 km WSW Invermere], Watch Peak 24 L. pensilis + BC, [11 km WSW Invermere], Watch Peak 25 L. pensilis ô UT, [Utah Co.,] $12 \mathrm{mi} \mathrm{N}$ Provo 26 L. pensilis $\widehat{\jmath}$ WA, Yakima Co., Bethel Ridge $\mathbf{2 7}$ L. pensilis + UT, Salt Lake City. 
specimen labelled simply "19/10" and probably not a syntype. A third specimen in MCZ (photo available at http://insects.oeb.harvard.edu/mcz/Species_record. php?id=1585), dissected and labelled as follows, is here designated as lectotype: "Dianthoecia / teligera / Type / Morr"; "Tex."; 27/10"; "Certainly not / vicina as / refined by Grote"; "Peab. Acad."; "Type / 1742"; "M.C.Z. Type \# / gen. 1742 / 28 Jan. 33 H[?]. B."; the following label will be added: "Lectotype / Dianthoecia / teligera Morr., 1875 / desig. by Schmidt 2015”. Type locality: Waco, Texas.

Diagnosis. Although closely related to $L$. vicina, the challenge in identifying $L$. teligera is in separating it from L. sareta in the southwestern Great Plains where the ranges of the two can overlap. Compared to L. sareta, L. teligera is slightly larger with a broader forewing and better-defined, crisper forewing maculation. Reliable identification should be based on genitalic structure, where L. teligera males have a medial and lateral field of short, ventrally directed spines above the juxta, rather than two large flanges laterally on the juxta with dorsally directed spines in $L$. sareta. The female $L$. teligera has an asymmetrical, invaginated ostium (like the opening of a conch), whereas that of $L$. sareta has a simple ostium with the margin of the prevaginal plate convex.

Distribution and biology. Lacinipolia teligera is known from the Great Plains of central Colorado and eastern Kansas southward to central Texas (Fig. 70). Nothing is known of the early stages, although these are undoubtedly similar to those of $L$. vicina.

Remarks. Lacinipolia teligera is closely related to L. vicina, and the two have previously been considered conspecific (as L. imbuna; Franclemont and Todd 1983). However the two differ structurally as outlined in the L. vicina diagnosis, in addition to a DNA barcode difference of $1.0 \%$. The two species occupy separate ecoregions and different habitats, with teligera in the grasslands of the Great Plains and vicina in deciduous forest of the Appalachian and Atlantic region.

\section{Lacinipolia pensilis (Grote, 1874)}

Figs 22-27, 57, 61, 65, 71

Dianthoecia pensilis Grote, 1874b: 199.

Type material. described from at least 1 male and 1 female syntype; the following male $[\mathrm{BMNH}]$ is here designated as lectotype: "Dianthoecia / pensilis $\widehat{\partial}$ / Type Grote" [red-bordered handwritten label]; "Type" [round, red-bordered, typed label]; Vancouver I / Grote Coll. / 81 - 116"; "5597”; Noctuidae / Brit. Mus. slide / No. 4912 O”" [blue type-written label]; the following label will be added: "Lectotype / Dianthoecia / pensilis Grote, 1874 / desig. by Schmidt 2015.” Type locality: Victoria, [Vancouver Island, British Columbia, Canada].

Diagnosis. Lacinipolia pensilis is a northwestern montane species that is often confused with $L$. sareta and also $L$. acutipennis in parts of the range. Compared to L. sareta, L. pensilis flies later (August to September versus June to early August), and differs 
considerably in genitalic structure of both males and females as outlined in the key and the $L$. sareta account.

Separating pensilis from dark forms of $L$. acutipennis, which are prevalent in montane habitats of the Pacific Northwest, poses the greatest identification challenge in the L. vicina group. Lacinipolia pensilis usually has better-defined forewing markings, richer brown tones in the forewing medial area, and no tendency for streaky pale patches in the forewing apical area; L. pensilis also averages slightly larger with a broader forewing. The spined crest of the male phallus is more robust and usually with more spines, and never has the thin apically-projecting spine that is normally found in L. acutipennis. In montane parts of the Pacific Northwest (interior British Columbia, northern and central Washington) habitat can help to separate the two, with $L$. pensilis occurring from dry montane woodland to high elevation subalpine forest, whereas $L$. acutipennis is characteristic of the dry, low-elevation habitats of the major intermontane valleys. See also remarks in the L. acutipennis account.

Distribution and biology. This species occurs in the western cordilleran region from central British Columbia and western Alberta southward to at least Washington and central Utah. The distribution pattern suggests it may occur farther south along the Cascade-Coast Ranges through Oregon, and further work is needed to establish the southwestern range limits. The larval description and host plants require clarification since the information given by Crumb (1956) and Godfrey (1972) was probably based on both $L$. acutipennis and $L$. pensilis. The larvae likely are ground-dwelling, general feeders on shrubs and herbs.

\section{Lacinipolia acutipennis (Grote, 1880), stat. rev.}

Figs 28-54, 58, 62, 66, 72

Mamestra acutipennis Grote, 1880: 214.

Mamestra doira Strecker, 1898: 7, syn. rev.

Mamestra ascula Smith, 1905b: 257, syn. rev.

$\dagger$ Polia pensilis ab. indistincta Strand, 1917: 28, unavailable; infrasubspecific name.

Lacinipolia subalba Mustelin, 2000: 13, syn. n.

Type material. Mamestra acutipennis: type female (BMNH; examined); type locality: Nevada. Mamestra doira: type female (FMNH, examined); type locality: Utah. Mamestra ascula: lectotype male designated by Poole (1982), (AMNH, examined); type locality: Stockton, Utah. Lacinipolia subalba: South rim of Los Peñasquitos Canyon, 76 m, San Diego Co., California (SDNHM).

Diagnosis. Lacinipolia acutipennis is a western steppe / grassland species that shows considerably greater regional phenotypic variation than others in the L. vicina group. In more mesic habitats (including higher elevations) of the Pacific Northwest and central Rocky Mountains L. acutipennis is replaced by the very similar $L$. pensilis. The two occur sympatrically in many transitional habitats, mostly dry montane woodlands at 


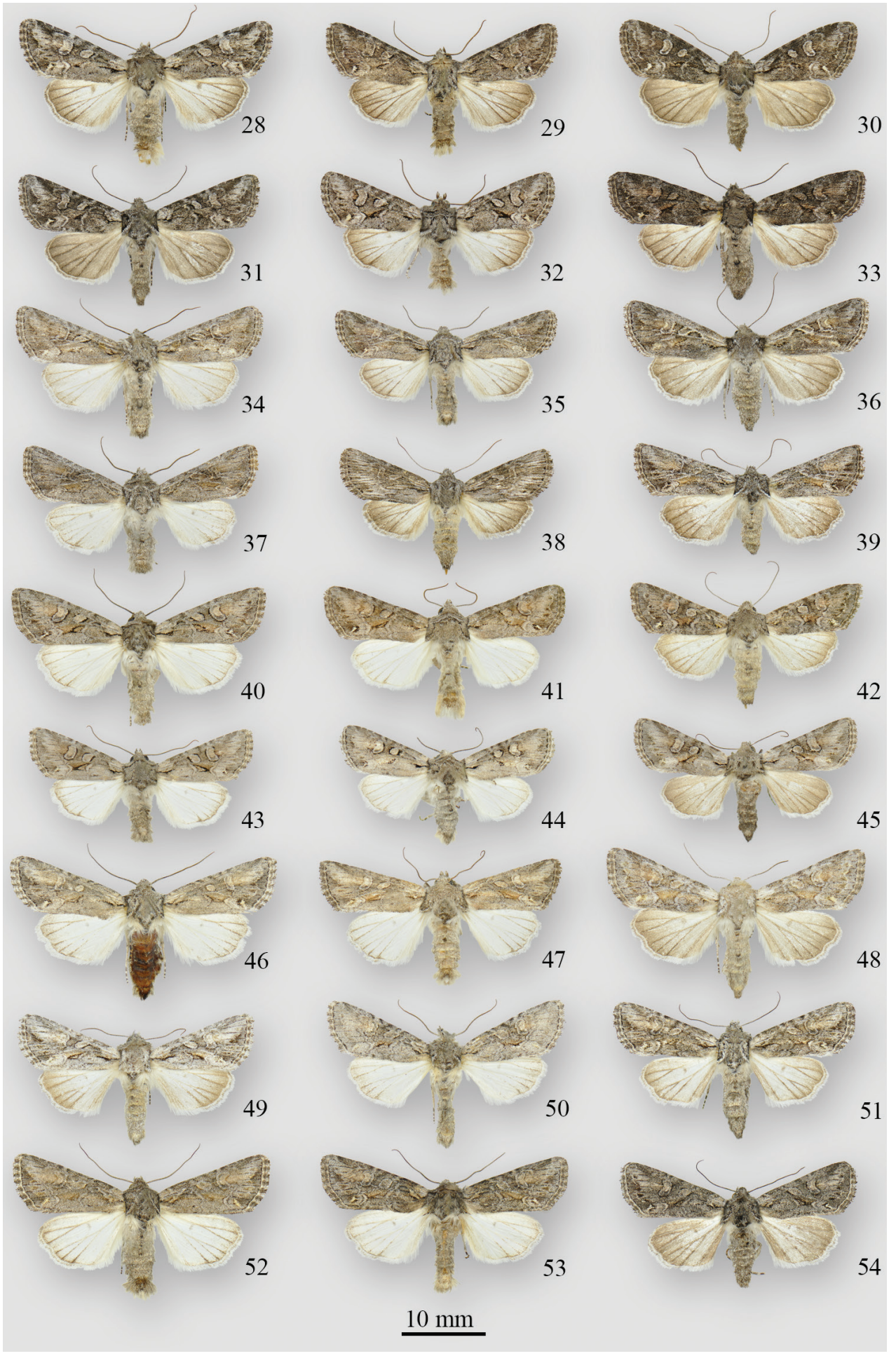


moderate elevations. Although phenotypes of $L$. acutipennis from the most arid habitats (e.g., Figs 34-39) can be distinguished from L. pensilis with relative ease, many northern L. acutipennis populations in the Pacific Northwest are dark, well-marked and very similar to $L$. pensilis, which makes identifying the two very difficult and led previous workers to conclude that they represent the same species. Compounding this difficulty is the lack of conspicuous genitalic differences that are otherwise typical of the genus. Despite the identification difficulties in the Pacific Northwest, other sympatric populations of $L$. acutipennis and $L$. pensilis have clearly different phenotypes. Differences are most pronounced in Great Basin populations (L. pensilis, Figs 25, 27 and L. acutipennis, Figs 49-51) and in the northern Rockies/Great Plains (e.g., Mon$\operatorname{tana} L$. pensilis, like those in Figs 23, 24, and L. acutipennis, Figs 46-48). The two differ in male genitalia structure as discussed below. These differences, in addition to a minimum 2.5\% divergence in DNA barcodes (Fig. 75), show that (at least) two species are involved.

Similar phenotypes of $L$. acutipennis and $L$. pensilis differ in the shape and size of the forewing, which averages more acute and smaller in L. acutipennis; the brown tones of the medial forewing are more muted in L. acutipennis compared to L. pensilis, giving an overall lower contrast in tone of the medial area with the grey-black antemedial and postmedial areas; the white spot in the anal angle is often more prominent in L. acutipennis, particularly in females; the forewing apex has a more contrastingly pale diffuse area that usually extends farther towards the reniform. In the male genitalia of $L$. acutipennis, the spinose crest of the phallus usually has a thin, delicate apically-directed spine (which is sometimes broken off, in which case the spine base is still evident), which is absent in L. pensilis; this thin spine is sometimes absent also in L. acutipennis, but in such individuals the entire crest is small and with fewer, smaller cornuti (Fig. 61c) compared to L. pensilis (Fig 62).

Two phenotypes have been recognized as separate species, $L$. doira of the Great Basin (Figs 49-51) and L. subalba of southern California (Figs 43-45). Clinal phenotypic variation, lack of diagnostic structural characters, and similarity in DNA barcodes, lead me to treat -doira and -subalba as regional forms.

Figures 28-54. Lacinipolia acutipennis adults. 28 BC, [Lillooet], Kirby Flats Rd. $\widehat{\jmath}$ BC, Savona, 2 mi SW 30 ㅇ BC, [Lillooet], Kirby Flats Rd., DNA voucher \# CNCNoctuoidea7978 3 I $\odot$ BC, [Lillooet], Kirby Flats Rd. 32 ๙ิ WA, [Okanogan Co.], Tonasket, 8 mi S 33 ๆ CA, Plumas Co., Jackson Ck. 34 ๙ WA, Douglas Co., Jameson L. 35 đ̊ WA, Grant Co., Dodson Rd. 36 q WA, Yakima Co., South Fork Ahtanum Cr. 37 OR, Crook Co., Suplee 38 OR, Lake Co., Alkali L. $39+$ OR, Baker Co., Burnt Ri-

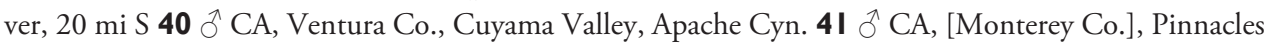
Nat. Mon. 42 † CA, [Monterey Co.], Pinnacles Nat. Mon. 43 $\lesssim$ [subalba paratype] CA, San Diego

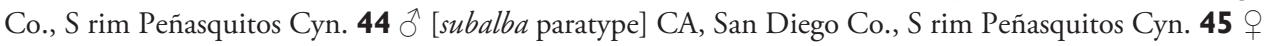
[subalba paratype] CA, San Diego Co., NAS Miramar 646 đ AB, Dinosaur PP 47 $\precsim$ MT, [Philips Co.],

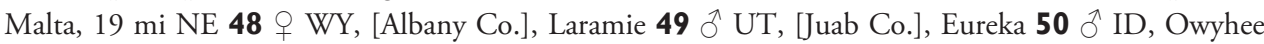

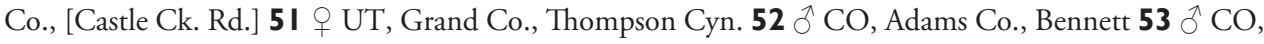
Larimer Co., Flatiron Reservoir $\mathbf{5 4}+$ CO, Larimer Co., Flatiron Reservoir. 


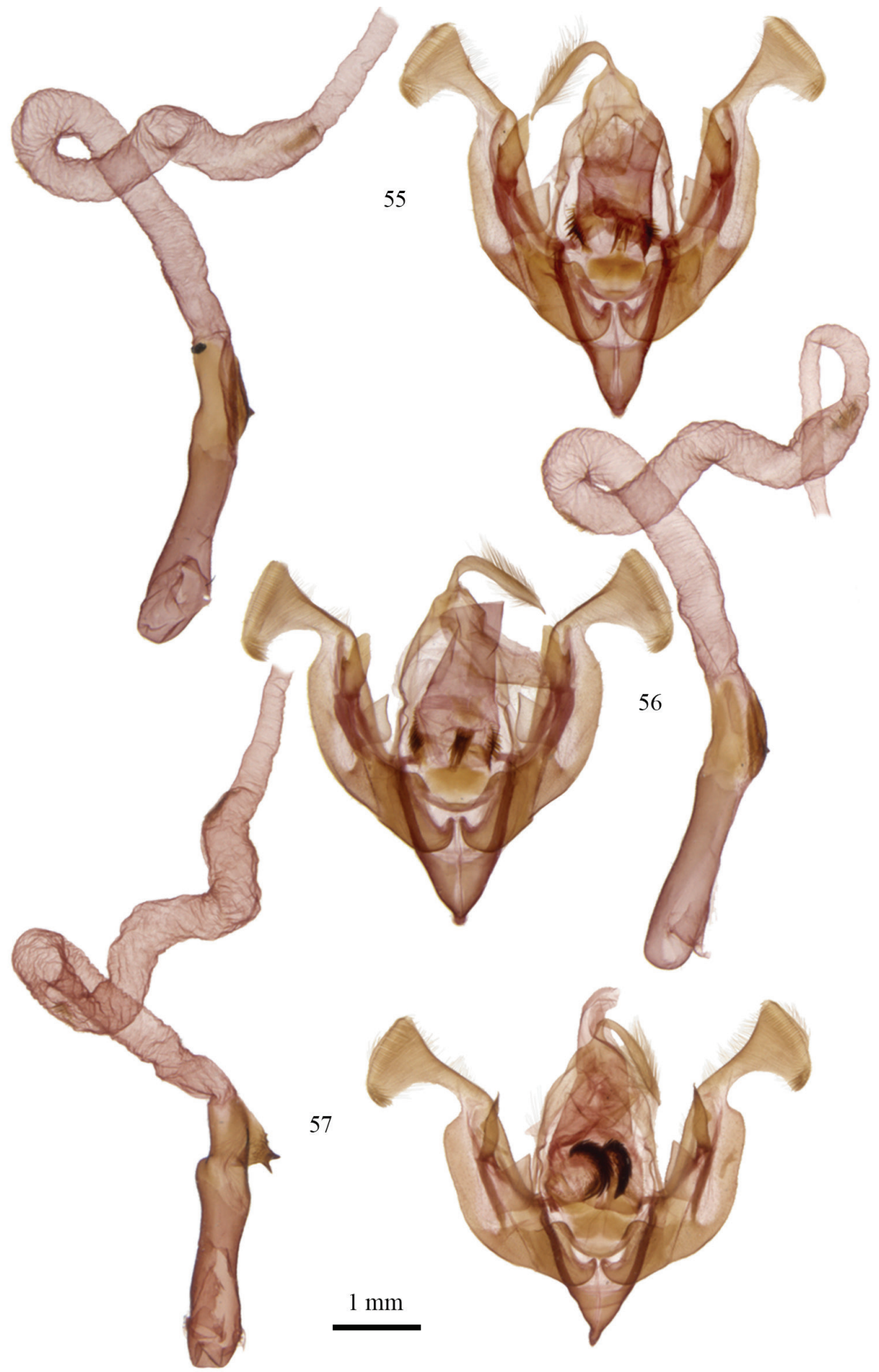

Figures 55-57. Lacinipolia male genitalia. 55 Lacinipolia vicina MA, Barnstable, CNC Gen. Prep. \# CNCLEP16884 56 Lacinipolia teligera TX, 6 mi E Canadian, CNC Gen. Prep. \# CNCLEP16886 57 Lacinipolia pensilis BC, Crowsnest, 5 mi NW, CNC Gen. Prep. \# CNCLEP16852. 
Distribution and biology. Lacinipolia acutipennis is a western species common throughout xeric, low elevation habitats of western North America. The core range includes the dry, western portions of the Great Plains, the Great Basin, and the western intermontane valleys north of the Sonoran zone, from southern Saskatchewan and Alberta southward to northern Arizona and New Mexico. Reports from Wisconsin (cited in Forbes 1954), Texas and southern Arizona (Hampson 1905) are probably misidentifications of L. sareta. Crumb's (1954) records from Nebraska and Kansas are plausible; the easternmost specimens I examined were from Watford City in western North Dakota. In the intermontane valleys west of the Rocky Mountains L. acutipennis occurs from southern British Columbia to southern California and northernmost Arizona and New Mexico (Fig. 72). All Pacific Northwest specimens examined from subalpine habitats and from sites west of the Coast Ranges proved to be L. pensilis.

The larval description and host plants require clarification since the information given by Crumb (1956) and Godfrey (1972) was probably based on both L. acutipennis and $L$. pensilis. The larvae likely are general feeders and may ascend shrubs to feed. Lacinipolia acutipennis flies in late summer with most specimens recorded from midAugust to late September.

Remarks. The name acutipennis has historically been associated with the taxon $L$. sareta (i.e. L. vicina of authors) rather than $L$. pensilis. This apparently stemmed from the fact that historical $L$. acutipennis specimens from western Nevada (the type locality of $L$. acutipennis) and adjacent northeastern California had been wrongly associated; a series from Truckee, California, examined by Lloyd Martin (and probably others before him, including McDunnough) consists of male L. sareta and female L. acutipennis, but only the male $L$. sareta were previously dissected. Female $L$. sareta from the northern Sierra Nevada and especially Nevada are considerably paler. Comparison of the type female of $L$. acutipennis to all other $L$. vicina-group taxa occurring in the region of the type locality shows that $L$. acutipennis is a dark female of the low-elevation taxon previously treated as a form of $L$. pensilis.

Variation in the DNA barcodes (Fig. 75) could be indicative of cryptic species, but genitalic structure is highly conserved and phenotypic blending is apparent from regions where adequate samples were available.

\section{Lacinipolia sareta (Smith, 1906)}

Figs 7-15, 59, 67, 73

Mamestra sareta Smith, 1906: 229.

Type material. lectotype male (AMNH, examined), designated by Todd (1982); type locality: Minnehaha, Yavapai Co., Arizona.

Diagnosis. Lacinipolia sareta is the most common and widespread species in the $L$. pensilis group, and most of the identification difficulties are in separating it from L. pensilis and $L$. acutipennis in the West. This is most reliably done based on genitalia, where 


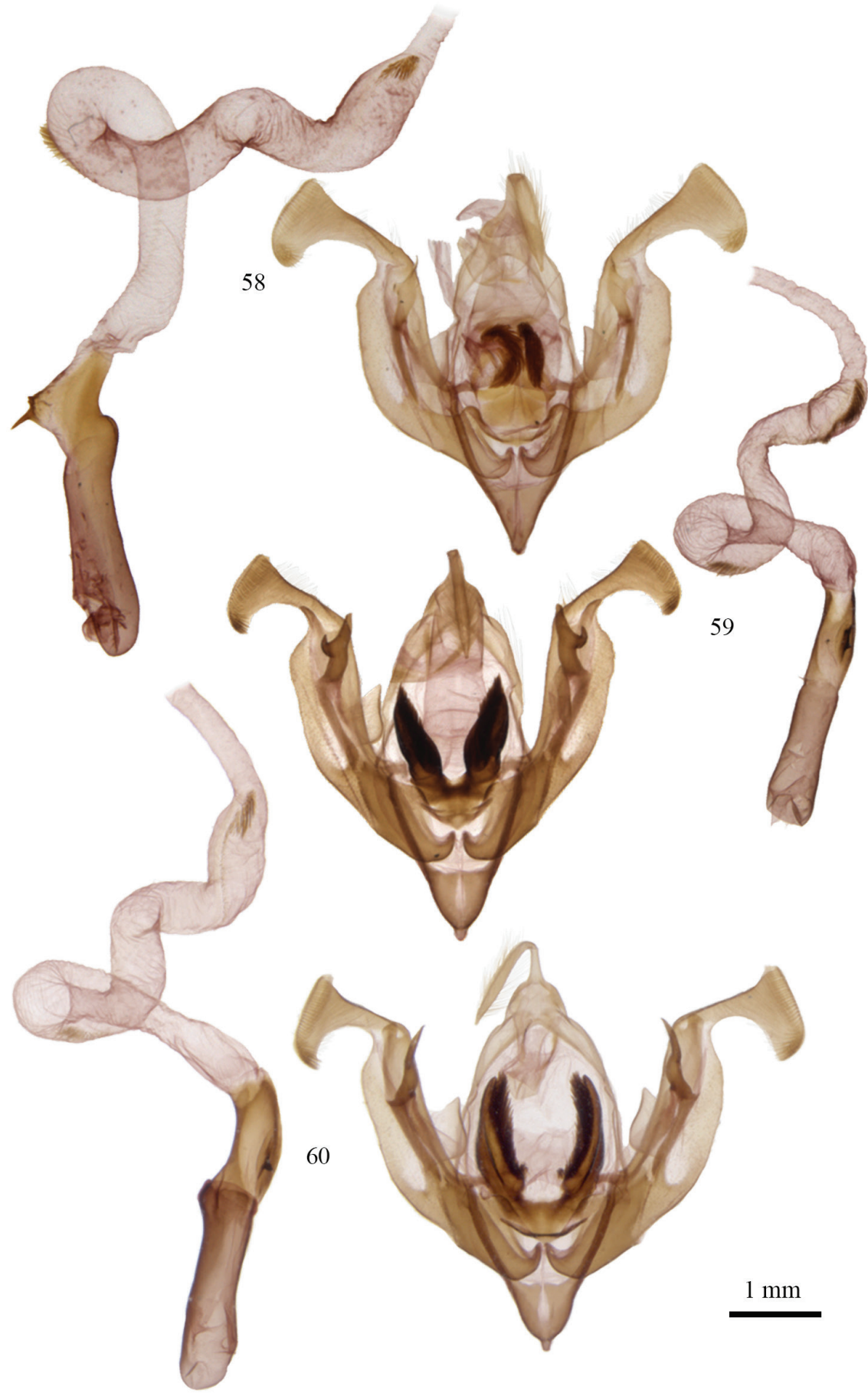

Figures 58-60. Lacinipolia male genitalia. 58 Lacinipolia acutipennis AB, Steveville, CNC Gen. Prep. \# CNCLEP16843 59 Lacinipolia sareta AZ, Prescott, CNC Gen. Prep. \# CNCLEP16867 60 Lacinipolia dimocki CA, Mt. Laguna, CNC Gen. Prep. \# CNCLEP16871. 
males lack the ventrally projecting, paired spinose crests above the juxta that are found in L. acutipennis and L. pensilis; females of L. sareta have a simple ostium with a strongly convex prevaginal margin, compared to those of L. pensilis and L. acutipennis which have an asymmetrical, conch-shaped ostium with a straight prevaginal margin. Lacinipolia sareta flies earlier in the year (mostly June-July) than L. pensilis and L. acutipennis (August-September), although the southernmost L. sareta populations in Arizona, New Mexico, and Texas fly again in late September-October after an initial May flight.

The remaining species (L. vicina, L. teligera, and L. dimocki) can, for the most part, be distinguished from L. sareta by geographic distribution; in Washington, Oregon and California, where the range of $L$. sareta overlaps that of L. dimocki, L. sareta is smaller and has a duller white hindwing, in addition to the genitalic characters given under dimocki. From eastern Colorado and New Mexico through western Oklahoma and northern Texas L. sareta overlaps with L. teligera; characters given in the keys and the L. teligera diagnosis will separate the two. The range of L. sareta might overlap with that of L. vicina in the East (from the Great Lakes region eastward through New York and New England), where the smaller size, different flight period and genitalic differences given under L. vicina will reliably separate the two.

Distribution and biology. Lacinipolia sareta occurs throughout western North America from the southern Yukon and Northwest Territories to Texas, Arizona and California; it undoubtedly also occurs in northern Mexico. It ranges eastward across the southern boreal region to at least Quebec, with an unverified record from Maine (Forbes 1954). Most or all records of L. vicina for Michigan (Moore 1955) probably apply to this species, but L. sareta is not known from Ohio (Rings et al. 1992) where it would be expected in sandy habitats along Lake Erie. Although found in a huge variety of woodland, steppe and prairie habitats, L. sareta particularly favours sandy soils and can be abundant in dune and beach habitats. Crumb (1956) describes the grounddwelling, polyphagous larva (as L. vicina). Godfrey (1972) illustrates the larva, and states that Arizona and Montana larvae are identical.

Remarks. The vast geographic range and considerable DNA barcode variation suggest that $L$. sareta could be a cryptic species complex. Alternatively, DNA barcode variation simply may not be fully congruent with species limits in the group, a phenomenon that occurs in about $10 \%$ of Noctuoidea (Zahiri et al. 2014). In contrast to the mtDNA variation, genitalic structure and wing pattern is highly conserved, and I could find no way to segregate specimens with divergent barcodes or those from different ecoregions. The shape of the digitus varies somewhat, with nominate L. sareta from the southwestern United States with a slightly longer, narrower tine-like digitus, compared to most (but not all) northern specimens, which have a shorter more triangular digitus, but the differences are inconsistent and again do not correlate with geographic or molecular differences. This is surprising given that molecular divergence among $L$. sareta haplogroups was greater than the minimum divergence between $L$. sareta and $L$. dimocki (Fig. 75), despite the considerable morphological differences between the two species. Studies of pheromone variation, nuclear DNA sequence data, and immature stages would provide more insight into this difficult group. 

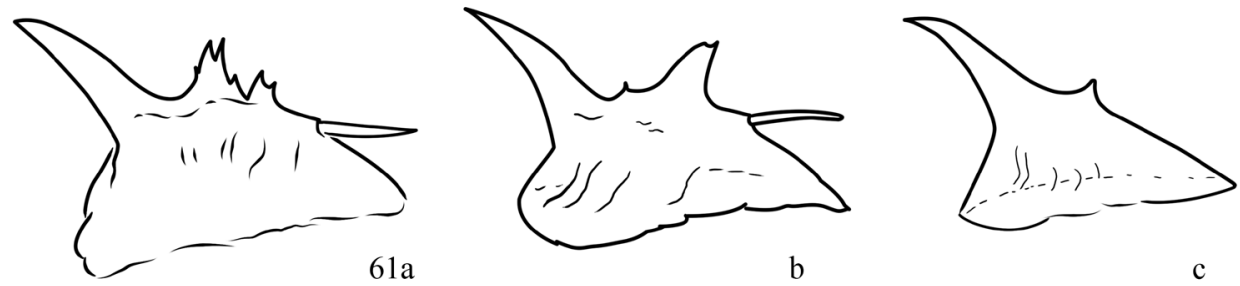

b

c
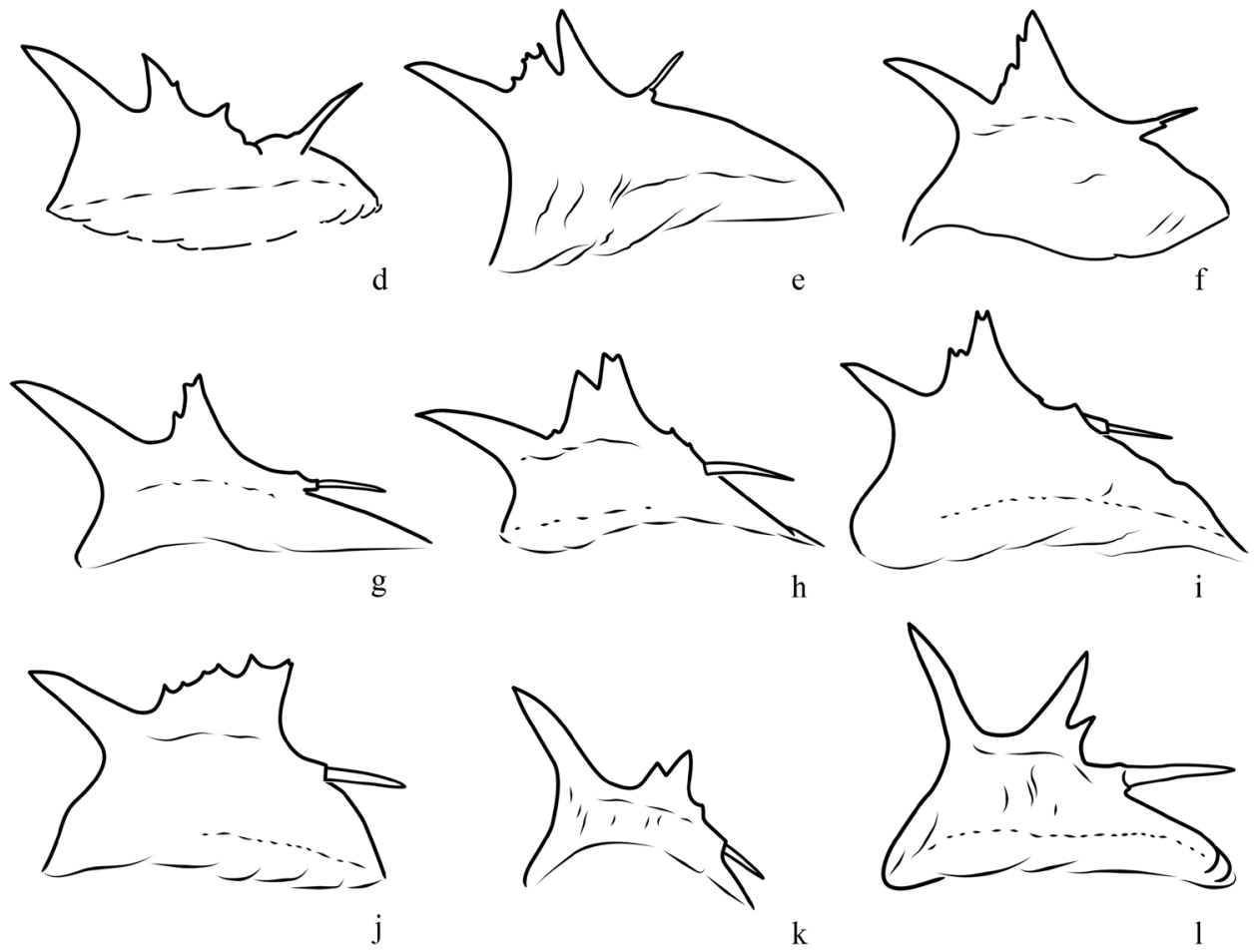

Figure 6I. Variation in spined crest of male phallus, Lacinipolia acutipennis. a-c UT, Stockton d NV, Ely e WA, Omak f WA, Tonasket g-h OR, Biggs i BC, Kamloops j BC, Keremeos k AB, Dinosaur PP I MT, Joliet.

\section{Lacinipolia dimocki Schmidt, sp. n.}

http://zoobank.org/3818A542-7458-4999-9547-F2DCFB980F1B

Figs $16-21,60,68,74$

Type material. Holotype ${ }^{\lambda}$. California: Ventura Co., Cuyama Valley, Apache Canyon, $0.6 \mathrm{mi} \mathrm{E}$ of Hwy. 33, 34.751193 $\mathrm{N}, 119.399772^{\circ} \mathrm{W}, 3497^{\prime}, 19 . J u n .2009, \mathrm{~T}$. E. Dimock [CNC]. Paratypes $17 \hat{\jmath} 18$ ㅇ․ Same data as holotype, $2 \hat{\gamma} 7$; ; California: Ventura Co., Pine Mountain, Pine Mountain campground, 6620', 21.Aug.2000, T. E. Dimock, $1 \delta^{\Uparrow} 1$ \% , 27.Jun.2000, 2 ; Ventura Co., Sespe Creek at Derrydale Creek, $34.583992^{\circ} \mathrm{N}, 119.262757^{\circ} \mathrm{W}, 15 . J u l .2009$, T. E. Dimock, $2 \bigcirc^{\Uparrow} 2$; ; Ventura Co., Sespe Creek at Tule Creek, $34.561350^{\circ} \mathrm{N}, 119.264780^{\circ} \mathrm{W}, 10^{\top}$; Ventura Co., 

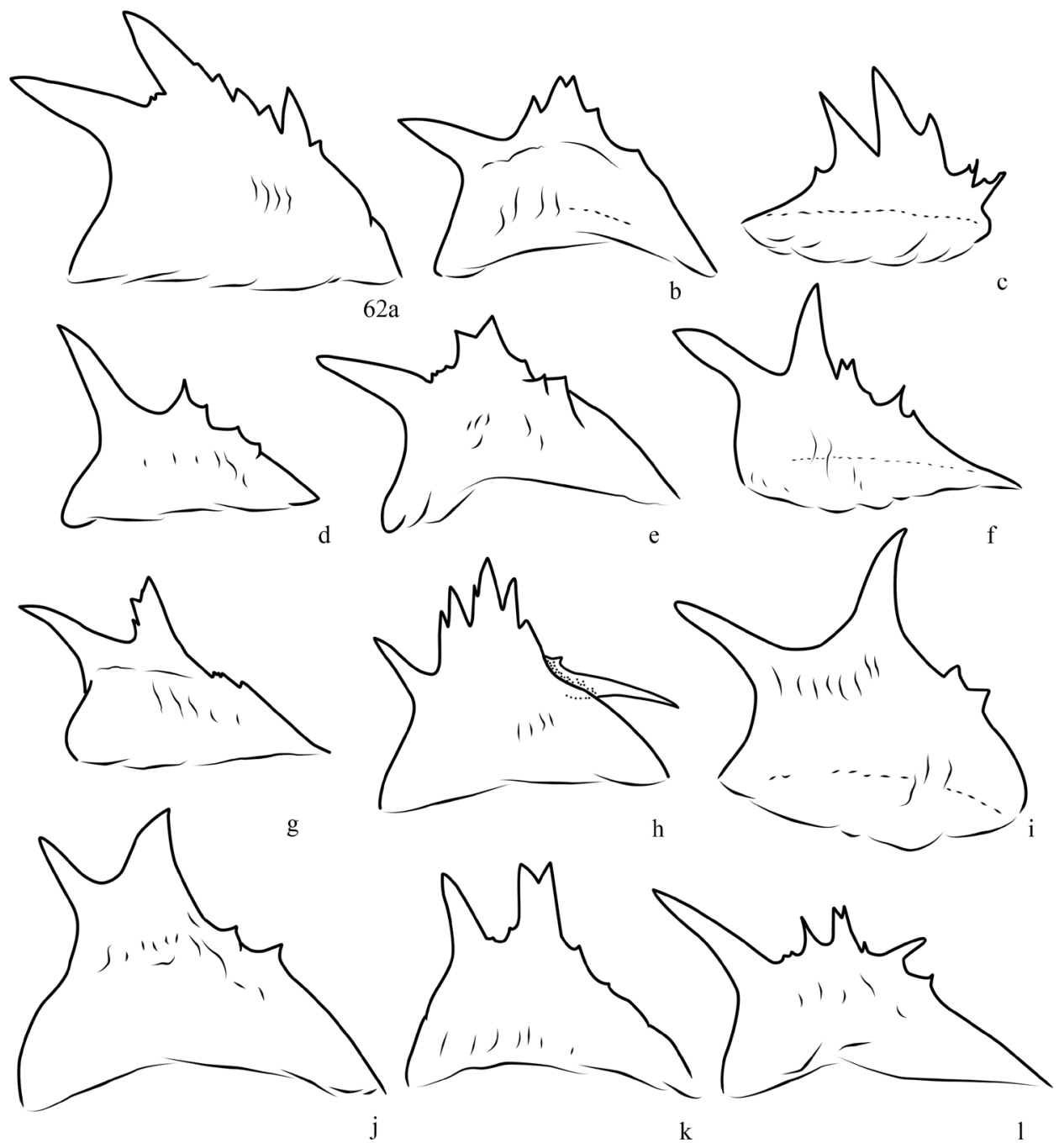

Figure 62. Variation in spined crest of male phallus, Lacinipolia pensilis. a WA, Satus Ck. b UT, Grantsville c MT, Brooks d UT, Logan e-f BC, Squamish $\mathbf{g}-\mathbf{h}$ BC, Wellington i BC, Riondel $\mathbf{j}$ BC, Crowsnest k BC, Okanagan Falls I BC, Squamish.

Upper Ojai Valley, $34.451^{\circ} \mathrm{N}, 119.121^{\circ} \mathrm{W}, 2120^{\prime}$, 31.May.2003, T. E. Dimock, $10^{\top}$; Ventura Co., Cuyama Valley, $34.695^{\circ} \mathrm{N}, 119.398^{\circ} \mathrm{W}, 3540^{\prime}$, 14.Jun.2005, T. E. Dimock, 3ð’; San Diego Co., Laguna Mountains, Pine Creek Road, 5500', 1.Jul.2000, T. Mustelin, 20; same data, DNA barcode vouchers \# CNCNoctuoidea7969 and CNC LEP00053134, 20; same locality, 29.Aug.2000, 19; San Diego Co., Laguna

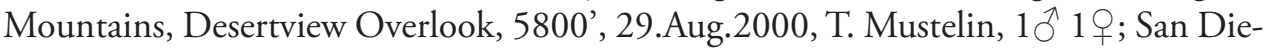
go Co., Laguna Mountains, Kitchen Creek Road, 5500', 29.Aug.2000, T. Mustelin, $10^{\Uparrow} 1$ \% ; San Bernardino Co., San Bernardino Mountains, Cactus Flats, $34^{\circ} 18.32^{\prime} \mathrm{N}$ 11647.99’ W, 6100', 25.May.2006, T. Mustelin, 1; San Bernardino Co., San Ber- 

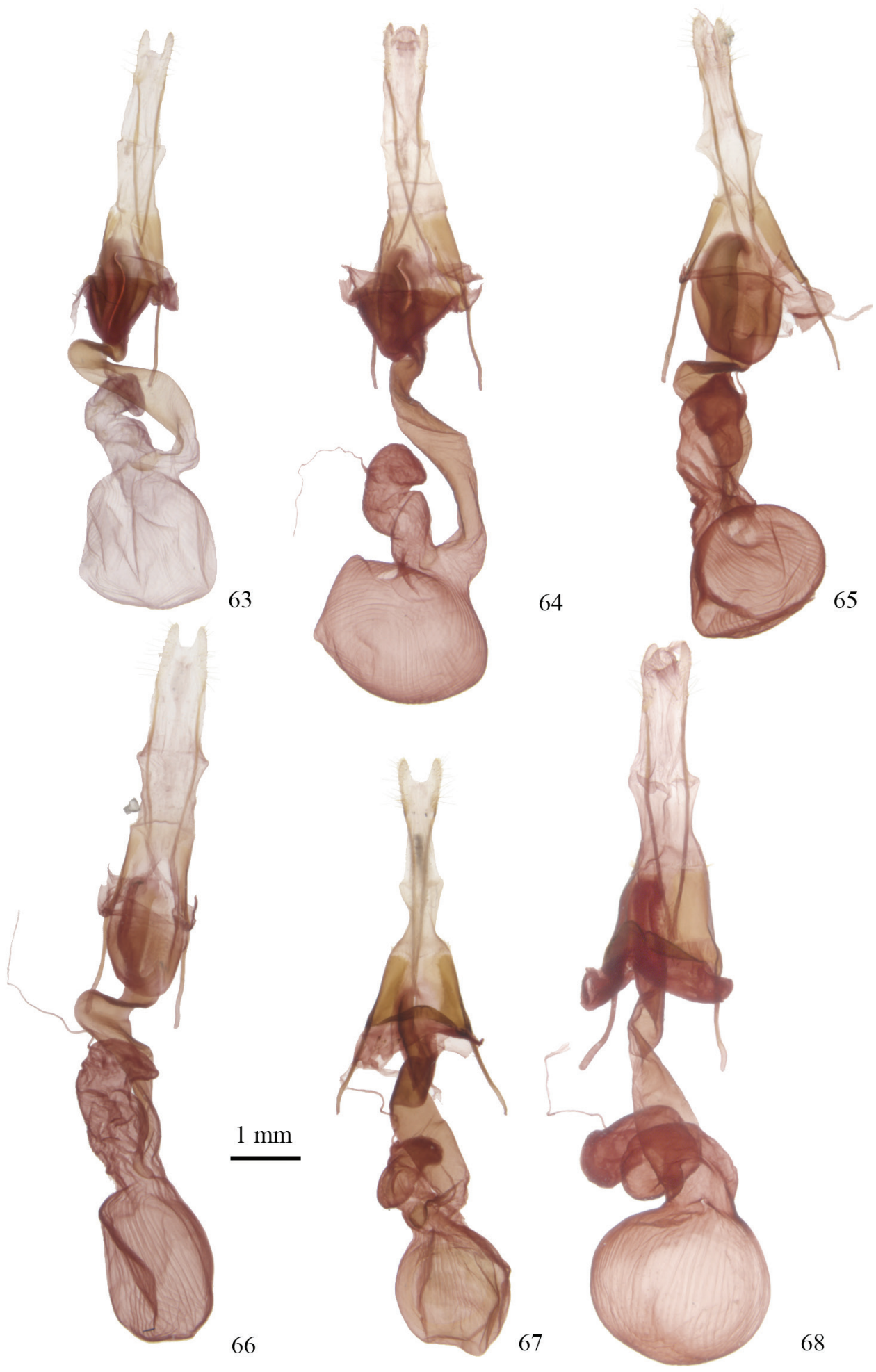
nardino Mountains, Onyx Summit, 34¹1.50’ N 116²3.06’ W, 8500', 25.May.2006, T. Mustelin, 19; 1.Aug.2006, 19; Riverside Co., Pinyon Crest, 33.614N 116.446 W 4200', 29.Sep.2001, R. Leuschner, 10. CNC, USNM. The type material is restricted to specimens from southern California.

Etymology. This species is named in honour of Thomas E. Dimock for his contributions to the knowledge of southern California moths. His efforts to collect research specimens provided most of the type series of $L$. dimocki.

Diagnosis. This western species was previously included with $L$. sareta (L. vicina of authors), but it is a cryptic, mostly parapatric species that replaces $L$. sareta from the Washington coast ranges southward through California. The two occur sympatrically in south-central Washington, and possibly elsewhere along the interface of the Great BasinCoast Ranges and Sierra Nevada. Externally $L$. dimocki is larger with an overall paler, less contrasting forewing pattern and usually a lighter, more pearly-white hindwing. The male genitalia differ in having a sinuate, tine-like clasper rather than the flattened, two-lobed clasper of $L$. sareta; also the ventral swelling of the phallus is much more pronounced in $L$. dimocki. Females can be difficult to separate from those of L. sareta; in addition to the forewing characters mentioned above, $L$. dimocki is generally larger overall and with a less sinuous, less dorsoventrally flattened ductus bursae and a relatively larger corpus bursae.

Description. Head. Antenna of male appearing filiform, but slightly serrate under magnification; antenna of female filiform; dorsal scaling grey; scape, and vertex with a mix of dull-white and dark-grey scales, these spatulate and bifid apically; frons with thin white, strap-like scales, bordered by transverse band of dark-grey scales at dorsal margin; labial palpi with mix of dull-white and dark-grey scales; $3^{\text {rd }}$ segment $0.4 \times$ length of $2^{\text {nd }}$ segment. Thorax. Vestiture of light-grey scales tipped with dark-grey apex; tegula and patagium with subterminal border of black scales, border of the tegula diffuse, but that of patagium forming distinct black prothoracic line; caudal margin with slight tuft; legs with mix of light- and dark-grey scales, tarsi with slight banding pattern formed by border of lighter scales along distal margin of each tarsal segment. Wings. Average forewing length of males $15.0 \mathrm{~mm}(\mathrm{n}=9$, range $14.2-15.8 \mathrm{~mm})$, females $15.1 \mathrm{~mm}(\mathrm{n}=9$, range $13.8-16.9 \mathrm{~mm})$; forewing ground colour pale grey, medial area pale grey brown; antemedial and postmedial line incomplete or absent, when present then best developed toward anal margin and fading out towards costa, antemedial line double, sometimes with slightly paler grey infill; postmedial line double, often forming pale, indistinct crescent opposite claviform spot; subterminal area with diffuse dark shading in subapical and anal areas, latter sometimes with a small white crescent; basal dash black and crisp; orbicular spot slightly oblong to slightly kidney shaped, with incomplete, thin black border and interior slightly paler than ground colour; reniform

Figures 63-68. Lacinipolia female genitalia. 63 Lacinipolia vicina MA, Barnstable, CNC Gen. Prep. \# CNCLEP16883 64 Lacinipolia teligera TX, 16 mi ESE Canyon, CNC Gen. Prep. \# CNCLEP16885 65 Lacinipolia pensilis BC, Mt. Kobau, CNC Gen. Prep. \# CNCLEP16840 66 Lacinipolia acutipennis CA, Truckee, CNC Gen. Prep. \# CNCLEP16847 67 Lacinipolia sareta AB, Wainwright Dunes, CNC Gen. Prep. \# CNCLEP16837 68 Lacinipolia dimocki CA, Plumas Co., Happy Valley, CNC Gen. Prep. \# CNCLEP16881. 


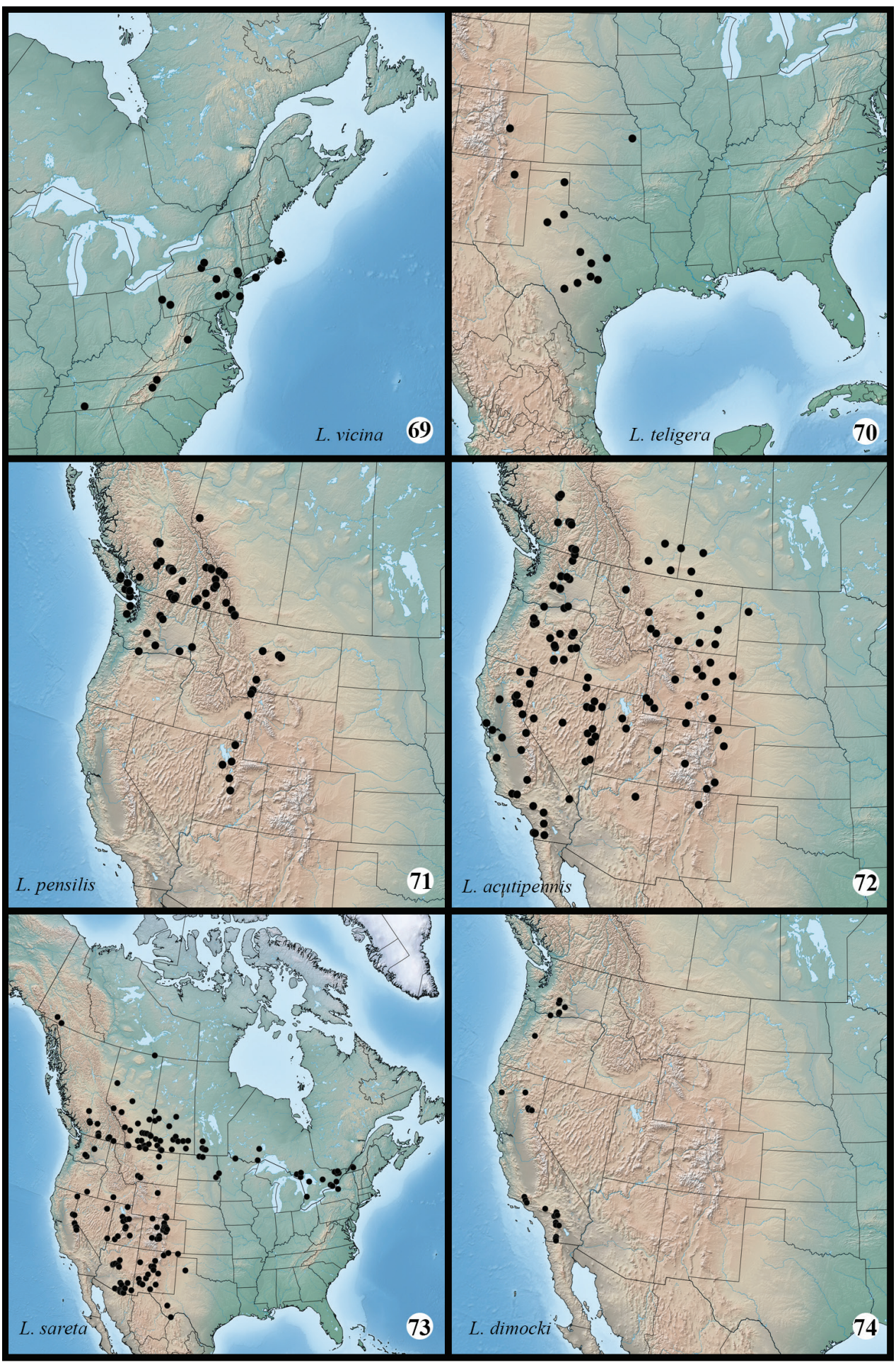

Figures 69-74. Distribution of examined specimens of Lacinipolia. 


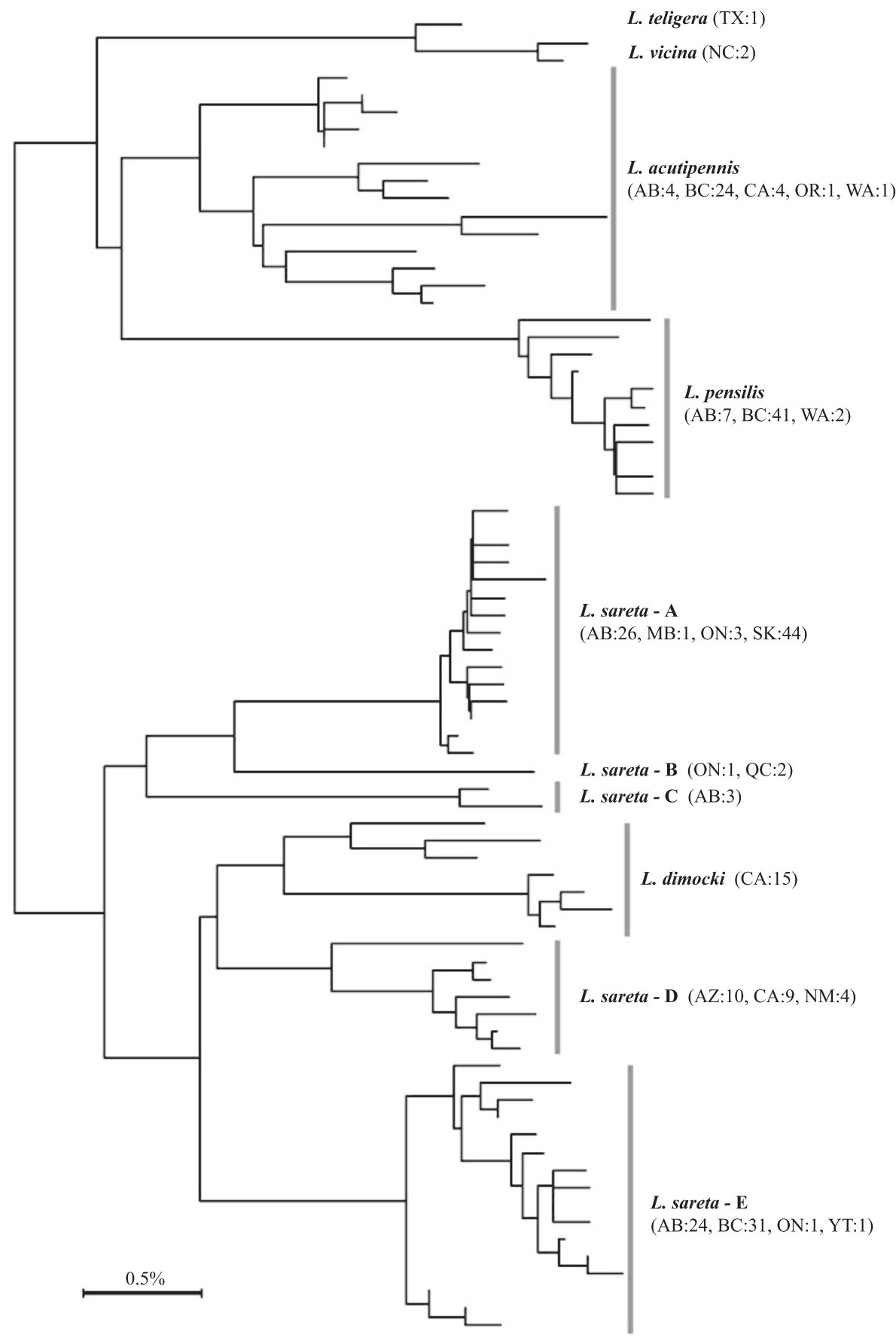

Figure 75. Neighbour-joining tree of representative mtDNA barcode haplotypes in species of the Lacinipolia vicina group. Sample size and locality are given in brackets, with number of specimens indicated after two-letter state/province abbreviation. Lacinipolia sareta variation is divided into five haplogroups, A-E. Voucher specimen data is given in Suppl. material 1. 
spot with incomplete thin black border, interior slightly paler than ground, with indistinct, darker inner ring; claviform usually distinct, forming a thin black, open V; fringe dark grey, pale grey at vein terminus resulting in indistinct striping; male hindwing bright, slightly pearlescent white with terminal third of veins, and thin diffuse margin fuscous; female hindwing duller white overall with more extensive fuscous shading on veins and marginal area. Abdomen. Vestiture light grey, first four segments with slight dorsal tufts of darker grey scales; tuft of $4^{\text {th }}$ segment most prominent. Male genitalia. Uncus slender, 10-11× longer than wide, evenly tapered from base to apex, with sparse long setae directed basad; valve with extreme subapical constriction forming a narrow neck, such that apex consists of strongly spatulate cucullus; valve abruptly angled caudoventrally beyond apical third; cucullus anvil shaped, interior surface densely covered with fine long hairs; corona consisting of a single row of flattened marginal spines, and a cluster of spines in tip of caudoventral lobe; sacullus with membranous, rectangular flap (possibly a modified editum), which is densely covered in long setae; clasper forming a long, simple sinuate tine, extending to, or slightly beyond, costa; digitus a simple flattened lobe, $2 \times$ longer than wide; juxta with two lateral, rounded triangular plates flanking phallus, these with short, straight dorsally directed spines on inner surface; phallus with ventral swelling $2 / 3$ from base; apical third curving ventrad slightly; phallus with small, broad-based, thorn-like dorsal cornutus at apical $3 / 4$; vesica directed leftventrad, then coiling dorsad and forming extended spiral through one rotation; vesica with small medial patch of spinules, and larger preapical patch extending slightly along axis of vesica. Female genitalia. Bursa copulatrix unisaccate; ductus bursae moderately sclerotized and dorsoventrally flattened, $5 \times$ longer than wide; corpus bursae globose, membranous and slightly corrugated, lacking signa; appendix bursae slightly coiled, with ductus seminalis situated preapically; ostium bursae extending caudad as an invaginated slit; prevaginal margin convex and slightly rounded-conical; terminal segments telescopic, with posterior apophysis twice as long as anterior apophysis; papillae small, narrow and lobe-like, membranous and moderately setose.

Distribution and biology. The early stages and larval food plants are unknown, but like other species in the group, larvae of $L$. dimocki probably are ground-dwelling and polyphagous on herbaceous plants. It occurs from the east slope of the Washington Coast Ranges to southern California.

\section{Acknowledgements}

I thank Jason Dombroskie (Cornell University, Ithaca, NY) and Michael Pogue (Systematic Entomology Laboratory, National Museum of Natural History, Washington, DC), for the loan of specimens, and Jocelyn Gill (CNC, Ottawa, Canada) for preparing genitalia slides, photography and the colour plates. Lars Crabo, Tom Dimock, Cliff Ferris, Paul Opler, Ken Stead, Bo Sullivan, Jim Troubridge and Jim Vargo kindly contributed specimens for this project. Don Lafontaine and Gary Anweiler provided valuable feedback and editorial comments. Paul Hebert and the staff at the Canadian Centre for DNA Barcoding (Biodiversity Institute of Ontario, University of Guelph, Guelph, Canada) provided 
data and information from the Barcode of Life Data (BOLD) system. Molecular analyses were carried out through grants from the National Science and Engineering Research Council of Canada and Genome Canada through the Ontario Genomics Institute.

\section{References}

Crumb SE (1956) The larvae of the Phalaenidae. Technical Bulletin no. 1135, United States Department of Agriculture, Washington, $356 \mathrm{pp}$.

deWaard JR, Ivanova NV, Hajibabaei M, Hebert PDN (2008) Assembling DNA barcodes: Analytical protocols. In: Martin Cristofre (Ed.) In Methods in Molecular Biology: Environmental Genetics. Humana Press Inc., Totowa, USA, 275-293. doi: 10.1007/978-1-59745-548-0_15

Forbes WTM (1954) Lepidoptera of New York and neighboring states. Part 3 Noctuidae.

Cornell University Agriculture Experiment Station, Memoir 329: 1-433.

Franclemont JG, Todd EL (1983) Noctuidae. In: Hodges RW, Dominick T, Davis DR, Ferguson DC, Franclemont JG, Munroe EG, Powell JA. Check List of the Lepidoptera of America North of Mexico. E. W. Classey Ltd., London and The Wedge Entomological Research Foundation Washington, 120-159.

Godfrey GL (1972) A review and reclassification of larvae of the subfamily Hadeninae (Lepidoptera, Noctuidae) of America north of Mexico. United States department of Agriculture, Technical Bulletin 1450, 265 pp.

Grote AR (1874a) Notes on American Lepidoptera with descriptions of twenty-one new species.

Bulletin of the Buffalo Society of Natural Sciences 2: 145-163.

Grote AR (1874b) New species of North American Noctuidae. Proceedings of the Academy of Natural Sciences of Philadelphia 1874: 197-214.

Hajibabaei M, deWaard JR, Ivanova NV, Ratnasingham S, Dooh R, et al. (2005) Critical factors for the high volume assembly of DNA barcodes. Philosophical Transactions of the Royal Society B 360: 1959-1967. doi: 10.1098/rstb.2005.1727

Hampson GF (1905) Catalogue of the Lepidoptera Phalaenae in the British Museum 5: 1-634. Hebert PDN, Cywinska A, Ball SL, deWaard JR (2003) Biological identifications through DNA barcodes. Proceedings of the Royal Society B: Biological Sciences 270: 313-321. doi: $10.1098 /$ rspb.2002.2218

Hebert PDN, deWaard JR, Zakharov EV, Prosser SWJ, Sones JE, et al. (2013) A DNA 'Barcode Blitz': Rapid digitization and sequencing of a natural history collection. PLoS ONE 8: e68535. doi: 10.1371/journal.pone.0068535

Ivanova NV, deWaard JR, Hebert PDN (2006) An inexpensive, automation-friendly protocol for recovering high-quality DNA. Molecular Ecology Notes 6: 998-1002. doi: 10.1111/j.1471-8286.2006.01428.x

Lafontaine JD (2004) The moths of North America. Noctuoidea: Noctuidae (part). Noctuinae (part - Agrotini). Fasc. 27.1. In: Dominick RB, Ferguson DC, Franclemont JG, Hodges RW, Munroe EG (Eds) The moths of North America. Wedge Entomological Research Foundation, Washington, D.C., 385 pp.

Leuschner R (1992) An overlooked record of Lacinipolia rodora (Noctuidae) from the United States. Journal of the Lepidopterists' Society 46: 79-80. 
Moore S (1955) An annotated list of the moths of Michigan exclusive of Tineoidea (Lepidoptera).

University of Michigan Museum of Zoology, Miscellaneous Publications No. 88, 87 pp.

Morrison HK (1875) List of a collection of Texan Noctuidae, with descriptions of new species.

Proceedings of the Boston Society of Natural History 17: 209-221.

Rings RW, Metzler EH, Arnold FJ, Harris DH (1992) The owlet moths of Ohio Order Lepidoptera Family Noctuidae. Ohio Biological Survey Bulletin, New Series 9(2): vi + 1-219, pl. $1-16$.

Selman CL (1975) Revision of the Genus Lacinipolia McDunnough of America North of Mexico (Lepidoptera: Noctuidae). Ph. D. thesis dissertation, Ohio State University.

Selman CL, Leuschner R (2001) Nine new species of Lacinipolia (Noctuidae) from Arizona, California and vicinity. The taxonomic Report of the International Lepidoptera Survey 2(8): 1-9.

Shorthouse DP (2010) SimpleMappr, an online tool to produce publication-quality point maps. http://www.simplemappr.net [accessed 2 December 2014]

Smith JB (1905a) New species of Noctuidae for 1905. Journal of the New York Entomological Society 13: 188-211.

Smith JB (1905b) New species of Noctuidae for 1905 - No. 2. The Canadian Entomologist 37: 257-261. doi: 10.4039/Ent37257-7

Smith JB (1906) New species of Noctuidae for 1906. No. 2. The Canadian Entomologist 38: 225-238. doi: 10.4039/Ent38225-7

Strand E (1917) Neue Aberrationen der Noctuiden - Subfamilien Hadeninae, Erastriinae, Catocalinae, Mominae, und Phytometrinae. Archiv für Naturgeschichte Berlin Abt. A82 2: 28-50.

Todd EL (1982) The noctuid type material of John B. Smith (Lepidoptera). United States Department of Agriculture, Technical Bulletin 1645: 1-228.

Wagner DL, Schweitzer DF, Sullivan JB (2011) Owlet Caterpillars of Eastern North America. Princeton University Press, New Jersey.

Zahiri R, Lafontaine JD, Schmidt BC, deWaard JR, Zakharov EV, Hebert PDN (2014) A transcontinental challenge — a test of DNA barcode performance for 1,541 species of Canadian Noctuoidea (Lepidoptera). PLoS ONE 9: e92797. doi: 10.1371/journal.pone.0092797

\section{Supplementary material I}

\section{Table S1. Specimen data for mtDNA barcode vouchers}

Authors: B. Christian Schmidt

Data type: data spreadsheet

Explanation note: Haplogroup numbers refer to those given in Fig. 75. Abbreviations for specimen depositories are as given in Methods and materials section.

Copyright notice: This dataset is made available under the Open Database License (http://opendatacommons.org/licenses/odbl/1.0/). The Open Database License $(\mathrm{ODbL})$ is a license agreement intended to allow users to freely share, modify, and use this Dataset while maintaining this same freedom for others, provided that the original source and author(s) are credited. 